\title{
簡易な前処理と自動装置を用いる絶縁油中の ポリ塩化ビフェニルのイムノアッセイ
}

\author{
大村 直也 ${ }^{\circledR 1}$, Thomas R. GLass ${ }^{1}$ ，佐々木和裕 ${ }^{1}$, 城 孝 司 $^{2}$, \\ 㠺見 幸弘 ${ }^{2}$, 横堀 尚之 ${ }^{3}$
}

\section{Simple Pretreatment Procedure and Automated Immunoassay System for Detection of PCBs in Transformer Oil}

\author{
Naoya Ohmura ${ }^{1}$, Thomas R. Glass ${ }^{1}$, Kazuhiro SASAkI ${ }^{1}$, Takashi JOH $^{2}$, \\ Yukihiro TAEMI $^{2}$ and Naoyuki YoKOBORI ${ }^{3}$
}

${ }^{1}$ Central Research Institute of Electric Power Industry, Environmental Science Research Laboratory, 1646 , Abiko, Abiko-shi, Chiba 270-1194

${ }^{2}$ Electric Power Engineering Systems Co., Ltd., 3-23, Nishiki-chou, Chiyoda-ku, Tokyo 101 - 0054

${ }^{3}$ Sumika Chemical Analysis Service, LTD., Ehime Laboratory, 3-1 - 39, Shinden-cho, Niihama-shi, Ehime 792 0003

(Received 22 September 2005, Accepted 26 October 2005)

\begin{abstract}
A simple and rapid preparation procedure of PCBs in transformer oil in conjunction with an immunoassay using an automated instrument for detecting PCBs is described. The joint column is used to prepare PCBs. The oil sample is introduced into a primary diatomite column containing fuming sulfuric acid and sulfuric acid to degrade the hydrocarbons, besides PCBs; the resulting hydrocarbons are removed by a secondary silica column. PCBs in the elusion are then extracted by dimethyl sulfoxide for an immunoassay. This preparation procedure can be performed within $30 \mathrm{~min}$., and the recovery ratio of PCBs is estimated to be in the range from $40 \%$ to $60 \%$. PCBs can be detected with an automated immunoassay instrument after mixing the dimethyl sulfoxide extract at $1 \%(\mathrm{v} / \mathrm{v})$ with an anti-PCB antibody solution. The assay is completed within $8 \mathrm{~min}$. The dynamic range is, respectively, from $0.3 \mathrm{ppm}$ to $18 \mathrm{ppm}$ for Kanechlor 300, from 0.2 ppm to 0.7 ppm for Kanechlor 400, and from 0.1 ppm to 1.5 ppm for Kanechlor 500 and 600 . This assay also enables one to detect PCBs as a total in fifteen oil samples in the range from $0.1 \mathrm{ppm}$ to $1.8 \mathrm{ppm}$ with a good correlation with the analysis using a highresolution mass spectrometer.
\end{abstract}

Keywords : PCB; immunoassay; transformer oil ; rapid detection.

\section{1 緒言 \\ ポリ塩化ビフェニル (polychlorinated biphenyl, PCB)}

は，その不燃性や絶縁性の高さから，変圧器やコンデンサ 一などの電気絶縁材あるいは熱媒体として使用された。し かし，1973 年に制定された「化学物質の審査及び製造等 の規制に関する法律」により，PCBの製造及び使用が禁 止され，既に使用されていた PCB は厳重に保管されるこ ととなった。 その後, 平成 13 年に「ポリ塩化ビフェニル 廃棄物の適正な処理の推進に関する特別措置法」が制定さ れ，保管されている PCBの無害化が進められている。現

\footnotetext{
${ }^{1}$ 財団法人電力中央研究所環境科学研究所：270-1194 千葉県我 孫子市我孫子 1646

2 株式会社電力テクノシステムズ：101-0054 東京都千代田区神 田錦町 3-23 西本興産錦町ビル 9 階

${ }^{3}$ 株式会社住化分析センター愛媛事業所: 792-0003 愛媛県新居 浜市新田町 3-1-39
} 


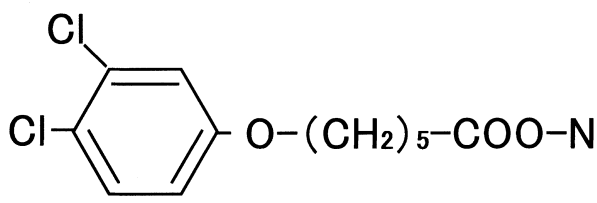

Formula: $\mathrm{C}_{16} \mathrm{H}_{17} \mathrm{NO}_{5} \mathrm{C}_{12}, \mathrm{MW}: 374$ 374.0561

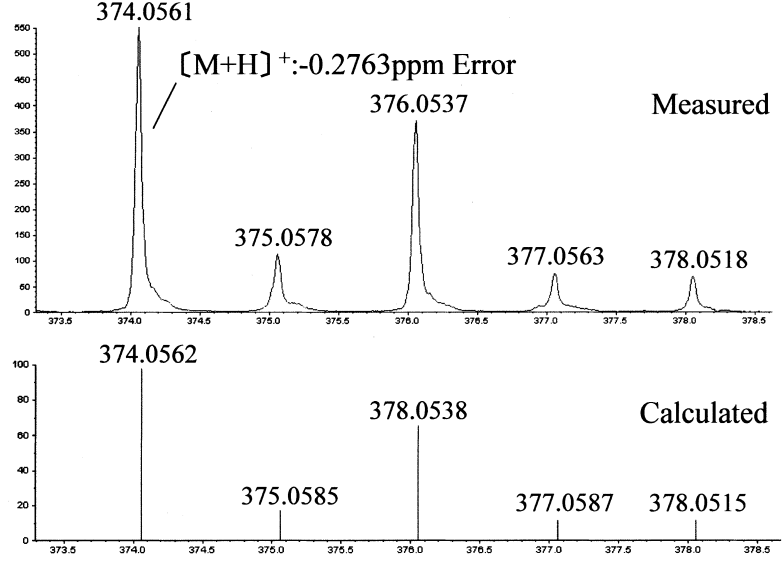

Fig. 1 The structure of 3,4-dichrolophenol related compound used as conjugate for solid phase

在, 無害化処理を行った油中の PCB の測定は高分解能ガ スクロマトグラフィー-高分解能質量分析, その他の廃棄 物については電子捕獲型検出器付きガスクロマトグラフ分 析により行われることになっている(1)2). しかし，これら の方法は, 測定に数日を要し, 費用も高価であることか ら，より簡易かつ迅速な測定法の開発が望まれている。

一方，近年になって簡易な環境分析の手段として生物検 定法が注目されている.イムノアッセイは，生物検定法の うち抗原抗体反応を利用する方法の総称である ${ }^{3)}$. PCB を 対象としたイムノアッセイでは，酵素免疫測定法 (enzymelinked immunosorbent assay, ELISA) が, EPA（US environmental protection agency) において測定法として登録 されている4). また, 魚や動物性脂肪中の PCB の検出に適 用した例 ${ }^{5) 6)}$, 環境試料中の PCBの検出を前処理とともに 検討した例がある ${ }^{7) ~ 9)}$. 最近, 無害化処理油中の PCB の 検出に ELISAを適用した例も報告されている ${ }^{10)}$. 一方, 酵素免疫測定法のほかには，化学物質と受容体への結合を 利用して遺伝子検出を行う受容体レポーターアッセイにつ いて, 環境試料中のコプラナー PCB を含むダイオキシン 類の検出 ${ }^{11)}$ や, 保管 PCB 廃棄物あるいは無害化処理油中 の $\mathrm{PCB}$ の検出について報告されている ${ }^{12) 13)}$. 更に $\mathrm{PCB} の$ 検出に関しては, 毛細管現象により薄膜上で抗原抗体反応 を行うイムノクロマトグラフィーを用いた報告がある ${ }^{14)}$.

しかし, 絶縁油中の PCB を検出するイムノアッセイは 現在のところ十分に開発が進んでいるとはいえない.この 理由の一つに，イムノアッセイに適合しうる簡易な前処理
法に関する情報が少ないことが挙げられる．抗原抗体反応 は，前処理後に測定液中に残存する絶縁油由来の成分や溶 媒により影響されることが予想される。このため, これら の測定に影響する因子を極力排除しつつ，迅速かつ簡便に 絶縁油から PCB を抽出できる前処理法が重要となる. イ ムノアッセイの利点である感度と迅速性を損なわないため には，より簡便な前処理法に高感度かつ迅速な測定法を組 み合わせることが必要である。

著者らは，これまでに蛍光蓄積並びに結合平衡除外効果 により，物質の定量に際して抗体の平衡解離定数まで検出 限界を達成しうるイムノアッセイを提案した ${ }^{15)}$ (18) , 本イ ムノアッセイを採用し, 女性ホルモンや農薬などの化学物 質をセミリアルタイムで検出できる自動装置を報告し た ${ }^{19)}$. 更に絶縁油中 PCB の迅速な検出を目指し, 前処理 法を検討してきた ${ }^{20)}$. 本報告では, 既報の前処理法を改善 し，更に自動装置を用いた測定系に適用することで，簡便 かつ高感度に絶縁油中 PCB を検出できるイムノアッセイ を構築した。

$$
2 \text { 実験 }
$$

\section{$2 \cdot 1$ 抗体及び化学物質}

各種カネクロールはジーエルサイエンスから購入した。 モノクローナルマウス抗 PCB 抗体（Research Diagnostics Inc. 製) を 1 次抗体， 2 次抗体として Cy-5 標識モノクロ ーナルヤギ抗マウス抗体（Jackson ImmunoResearch 製） を使用した。

\section{$2 \cdot 2$ 担体の調製法}

アガロースビーズ（NHS-activated Sepharose ${ }^{\mathrm{TM}} 4$ fast flow, Amercham Biosciences 製) を固相担体として使用 した。ビーズ担体の活性化は以下の手順に従って行っ た ${ }^{19) 20)}$. ビーズ容量 $1 \mathrm{ml}$ となるように懸濁液を採取し, $1 \mathrm{ml}$ の $1 \mathrm{mM} \mathrm{HCl}$ で 10 回洗浄した. 更に $1 \mathrm{ml}$ の生理食 塩水 (phosphate buffered saline, pH 7.5, PBS) にて 10 回洗浄した後， $0.9 \mathrm{ml}$ の PBSに懸濁した。次に合成した ジクロロフェノール誘導体（Fig. 1）と牛血清アルブミン (bovine serum albumin, BSA) の複合体を $1 \mathrm{mg} / \mathrm{ml}$ の濃 度で含む PBS 溶液を懸濁液に $0.1 \mathrm{ml}$ 添加した。室温にて 2 時間振とうした後, $100 \mathrm{mg} / \mathrm{ml}$ の濃度で BSA 含む PBS 溶液を $0.1 \mathrm{ml}$ 添加し, 更に 2 時間振とうした. 振とう後, ビーズを $30 \mathrm{ml}$ の PBSに懸濁し, 後に記載する検出セル に充填した。

\section{$2 \cdot 3$ 絶縁油前処理法}

珪藻土カラム（Merk 製, Extrelut NT3）とシリカゲル カラム（Waters 製，SepPak Silica Plus）を連結した。こ の後, $1 \mathrm{ml}$ の $25 \%$ 発煙硫酸, $2 \mathrm{ml}$ の濃硫酸を珪藻土カラ 


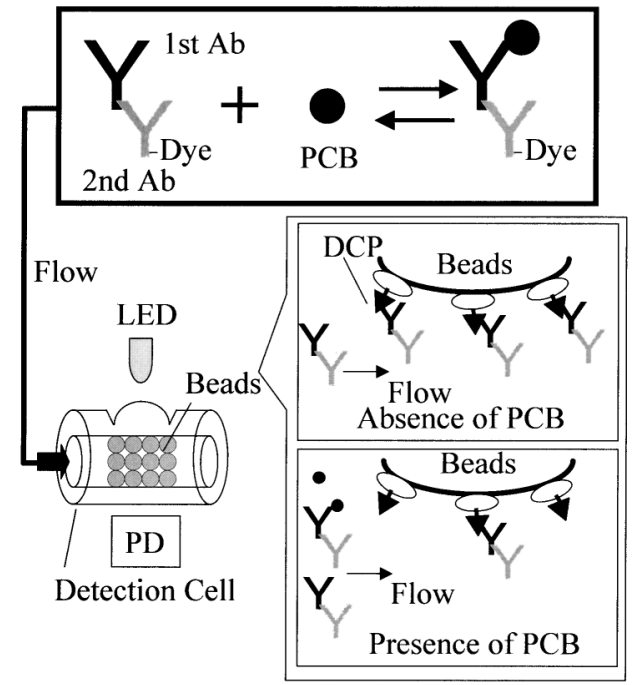

Fig. 2 The principle of immunoassay for automated system

DCP describes for 3,4-dichrolophenol related compound shown in Fig. 1.

ムに順次添加し，15 分間放置した. $1.5 \mathrm{~g}$ の無水硫酸ナト リウムを珪藻土カラムに重層した後， $0.5 \mathrm{~g}$ の絶縁油を添 加し, 絶縁油をカラム内に浸透させるため $1 \mathrm{ml} の n$-へキ サンを追加で添加した. 5 分間放置して絶縁油成分の分解 を促した後，展開を行った． $5 \mathrm{ml}$ の $n$-ヘキサンを添加し て液面が無水硫酸ナトリウム層まで下がったら，10 $\mathrm{ml}$ の $n$-ヘキサンを更に加えて溶出液の全量をナス型フラスコに 回収した。 $0.5 \mathrm{ml}$ のジメチルスルホキシド（DMSO）を加 え, $30^{\circ} \mathrm{C}$ の湯浴中でロータリーエバポレーターで $n$-ヘキ サンを除去した，この後，残液をマイクロチューブに移し て遠心分離（2000 rpm，5分間）し，DMSO 層を分取し て前処理液とした。

\section{$2 \cdot 4$ 測定法}

イムノアッセイの測定は検出セルで行った ${ }^{19)}$ 。この中空 状のセル内にはビーズ担体が充填されており，上記の手順 で調製した絶縁油前処理液に抗体の混合溶液（1 次抗体： マウス抗 PCB モノクローナル抗体, 2 次抗体：Cy-5 標識 ヤギ抗マウス抗体）を加えてセルに送液した。抗体の混合 溶液中では, 1 次抗体は 2 次抗体が結合した標識体として 存在する。絶縁油に PCB が含まれる場合, 1 次抗体は抽 出液中の $\mathrm{PCB}$ と結合平衡に達し, $\mathrm{PCB}$ の濃度に応じて未 結合抗体と抗体- PCB 結合体となる。この結合平衡液を 検出セルに送液すると，抗体一 PCB 結合体を形成したも のは検出セルを素通りし，未結合抗体のみが検出セル内に あるジクロロフェノール誘導体と結合する．このため，検 出セル内に捕捉された抗体量から PCB 濃度を定量するこ とができる，一方，絶縁油に PCB が含まれていない場合，

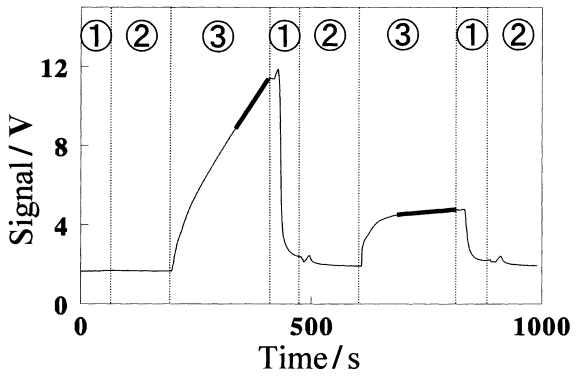

Fig. 3 Typical trace of signal in assay operation

The assay was performed with flowing $25 \mathrm{mM} \mathrm{NaOH}$ (1), PBS-BSA buffer (2) and sample solution (3) in this order. This cycle was repeated two times for following samples. First sample contains no PCB and the second one contains excess amount of PCB. The trace of signal expressed as a solid line, and the portion of the bolded line described as the term for the signal slope collection for PCB determination.

1 次抗体はその全量が未結合抗体であり, 検出セル内にあ るジクロロフェノール誘導体と結合するので，セル内に捕 捉される抗体量が多くなる.よって，捕捉された抗体量の 比較から, 絶縁油の PCB 污染の有無を知ることができる (Fig. 2)。な押，七ル内に捕捉された抗体量は，2次抗体 上の色素からの蛍光として光学的に計測した ${ }^{19}$. 具体的に は, 検出セルに励起光を照射し, 得られる蛍光をフォトダ イオードによって電気信号として計測した。絶縁油中の PCB 濃度が高いほど信号值が小さくなり, その減少から 絶縁油中の PCB 濃度を測定した（Fig. 3). 本法では，試 料の送液によって連続的に抗体をセル内に捕捉して蛍光信 号の蓄積を行うこと, 液相（測定溶液）と固相（ビーズ担 体）の接触時間が短いため, 両相の間で競合反応が起こり

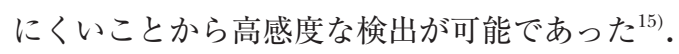

イムノアッセイの測定は, 検出セルを自動装置に装着し て行った ${ }^{19}$ ，検出セルへ送液する溶液の種類，量，速度は 装置に接続したコンピュータ上で任意に設定した。また， 蛍光信号值（励起波長 $620 \mathrm{~nm}$ ，測定波長 $670 \mathrm{~nm}$ ）は同 ビコンピュータ上に毎秒ごとに記録した（Fig. 2).

抗体溶液は以下の手順で調製した. 1 次抗体及び 2 次抗 体は，共に $0.1 \%$ （w/w）BSA を含むPBS（PBS-BSA）で 希釈して用いた。 1 次抗体と 2 次抗体の濃度は, それぞれ $500 \mathrm{pM}$ と $2 \mathrm{nM}$ とした。一方, 各種絶縁油（PCB を含ま ない未使用絶縁油と，これにカネクロールを添加した絶縁 油, 加えて PCB 混入使用済み絶縁油) は前述の操作に従 って前处理液を調製した。また，各種カネクロール溶液は DMSO で希釈して用いた。

これらの抗体溶液, 前処理液及びカネクロール溶液を用 いて以下の手順で測定液を調製した。まず抗体溶液を分取 した。これに前処理液, カネクロール溶液あるいは 
Table 1 The effect of fuming sulfuric acid ratio on isomer recovery

\begin{tabular}{llrrrrr}
\hline \multicolumn{2}{l}{$\begin{array}{l}\text { Fuming sulfuric acid/ml } \\
\text { Sulfuric acid/ml }\end{array}$} & 0.0 & 0.5 & 1.0 & 2.0 & 3.0 \\
Recovery of & Tri & 94 & 86 & 81 & 33 & 6 \\
isomers, \% & Tetra & 94 & 87 & 91 & 63 & 38 \\
& Penta & 92 & 95 & 99 & 94 & 71 \\
& Hexa & 106 & 103 & 95 & 95 & 93 \\
& Hepta & 103 & 105 & 103 & 100 & 96 \\
& Octa & 96 & 91 & 91 & 89 & 88 \\
& Total & 97 & 93 & 92 & 72 & 53 \\
\hline
\end{tabular}

The total volume of fuming sulfuric acid and sulfuric acid is fixed at $3 \mathrm{ml}$. The ratio of fuming sulfuric acid was thus varied with changing sulfuric acid volume in the total. The recovery of isomers was calculated from the measured concentration by mass spectrometer and presented as the percentage for the added concentration.

DMSO のうち 2 種を任意に組み合わせて等量ずつ添加し て測定液を調製した。このとき，測定液中の DMSO 濃度 は $2 \%(\mathrm{v} / \mathrm{v})$ とした。調製した測定液は自動装置に供し た。自動測定は検出セルに $25 \mathrm{mM} \mathrm{NaOH}$, PBS-BSA，測 定液の順に送液して行った。絶縁油試料の場合, $1 \mathrm{ml}$ の $25 \mathrm{mM} \mathrm{NaOH}$ を $1 \mathrm{ml} / \mathrm{min}, 1 \mathrm{ml}$ の PBS-BSA を 0.5 $\mathrm{ml} / \mathrm{min}, 1 \mathrm{ml}$ の測定液を $0.25 \mathrm{ml} / \mathrm{min}$ で順次送液した (Fig. 3). 信号值は測定液の送液時において時間当たりの 変化值 $(\mathrm{mV} / \mathrm{s})$ として算出した。また，相対信号值は， PCB を含有していない対照測定液に対する百分率として 求めた。

\section{$2 \cdot 5$ 絶縁油中 PCB の高分解能質量分析}

絶縁油中 PCB の前処理及び測定は, 高分解能質量分析 で，特別管理一般廃棄物及び特定管理産業廃棄物に係る基 準の検定方法 別表第二（平成 4 年厚告 192 号, 平成 15 年環告 14 号改正）に準じて行った。なお，測定に使用し た装置は, 高分解能ガスクロマトグラフ - 高分解能質量分 析計 (HRGC: HP 6890N, Agilent 製, HRMS: AutoSpec NTS，Micromass 製）である。

\section{$2 \cdot 6$ 分子量測定と構造解析}

ジクロロフェノール誘導体の分子量測定と構造解析は QSTAR $^{\circledR}$ XL MS/MS System（アプライドバイオシステム ズ製）を用いて行った.

\section{$2 \cdot 7$ 校正曲線の作成方法}

本報告では，すべての校正曲線は既報 ${ }^{19)}$ に従って作成し た。具体的には, 式 ( 1 ) を用いて求めた。なお，相対信 号値は，信号の時間変化 $(\mathrm{mV} / \mathrm{s})$ から算出した.

$$
\operatorname{Sig}=100 /\left\{1+(x / a 1)^{\mathrm{a} 2}\right\}
$$

Sig：相対信号值（\%)，a1：相対信号值の $50 \%$ を与え る試料の PCB 濃度, $\mathrm{a} 2$ ：曲線の傾き， $x$ : 試料の PCB 濃 度.

$$
3 \text { 結 果 }
$$

\section{$3 \cdot 1$ 前処理法の検討}

既報ではイムノアッセイの前処理として，絶縁油中の PCB をDMSO 分配により抽出し, その前処理液を測定に 供する方法を報告した ${ }^{20)}$ 。この前処理法は，簡便である反 面，PCBとともに絶縁油成分が抽出されるため，抗体溶 液に前処理液を $0.1 \%(\mathrm{v} / \mathrm{v})$ 以上の濃度で添加すると絶縁 油成分に由来する白濁が生じやすい問題があった。このた め, 前処理液の添加量に上限があり, 検出感度の向上を図 る上で障害となっていた。本報告では，抗体溶液に前処理 試料を $1 \%(\mathrm{v} / \mathrm{v})$ 濃度で添加できるよう，絶縁油成分を 発煙硫酸・硫酸を含浸したカラム処理にて分解し，シリカ ゲルカラムでその一部を除去する前処理法を検討した。用

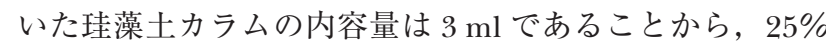
発煙硫酸と濃硫酸の合計が $3 \mathrm{ml}$ となるように両者の含浸 比を変えた。具体的には，0〜3.0 $\mathrm{ml}$ の $25 \%$ 発煙硫酸を 珪藻土カラムに添加し, 続けて $0 \sim 3.0 \mathrm{ml}$ の濃硫酸を加え て含浸比の異なるカラムを調製した。 これらのカラムに 4 種のカネクロールの混合物（等重量の KC300, KC400, KC500，KC600を混合）を 2 ppm となるように添加した 未使用絶縁油 $0.5 \mathrm{~g}$ をカラムに投入して分解を促した。そ の後, 珪藻土カラムに連結したシリカゲルカラムを通じ て，n-ヘキサンで溶出した。なお，シリカゲルカラムは発 煙硫酸処理後に残存が予想される着色物質や極性物質を除 去する目的で追加した．溶出液中の $\mathrm{PCB}$ を $８$ 塩素同 属体ごとに低分解能質量分析計にて測定し，カラム処理に おける回収率を算出した（Table 1)。発煙硫酸の含浸比 が高いと，3〜 5 塩素同属体の分解が進み，特に発煙硫酸 の含浸量が $1.0 \mathrm{ml}$ を超えると顕著な回収率の低下が観察 された。そこで，PCBの回収に影響しにくい含浸比（発 煙硫酸 $1.0 \mathrm{ml}$ 及び濃硫酸 $2.0 \mathrm{ml}$ ）を前処理法に採用した. この含浸比でカラム处理を先の 4 種のカネクロールの等 比混合物を $20 \mathrm{ppm}$ の濃度で添加した未使用絶縁油につい て行った。この後, 溶出液に $0.5 \mathrm{ml}$ の DMSO を加えてエ バポレーターで $n$-ヘキサンを除去し，DMSO 層の少量を 採取して前処理液とした。この前処理液中の $\mathrm{PCB}$ を 3 8 塩素同属体ごとに分析した結果，カラム処理と DMSO 分 配を含む前処理における PCB 回収率は，およそ $43 \%$ $(n=1)$ と推定された。これらの前処理液を抗体を含む PBS-BSAに $1 \%$ （v/v）濃度で添加したところ，白濁は見 られなかった。これは，白濁を起こす絶縁油成分が前処理 液からカラム処理により分解・除去されたためと考えられ た。以降は，この前処理法に従って実験を行った。 

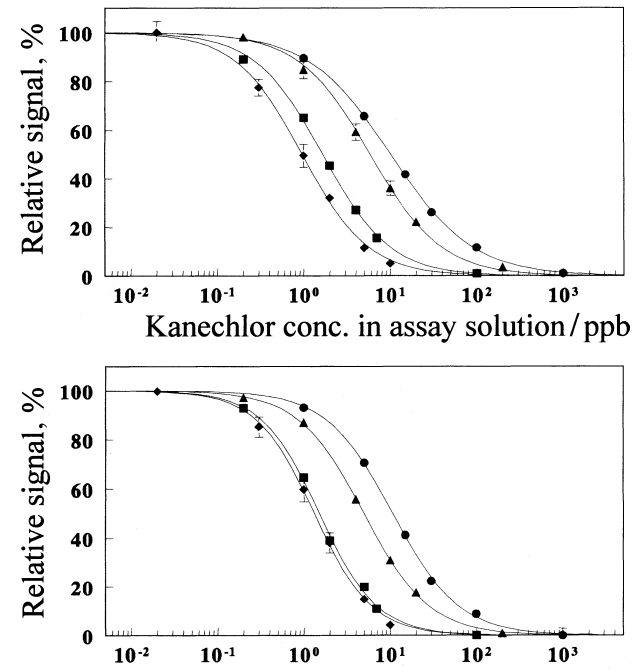

Kanechlor conc. in assay solution/ppb

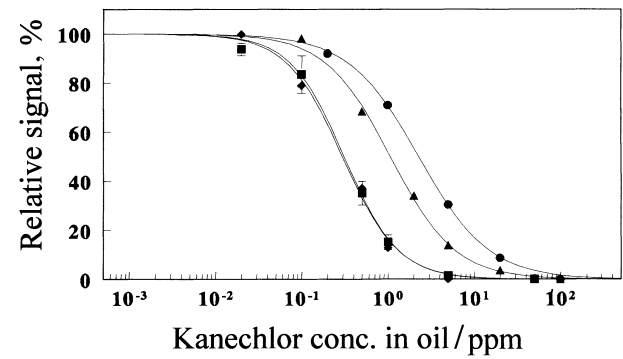

Fig. 4 Standard curves for various Kanechlor The type of Kanechlor was expressed as KC300

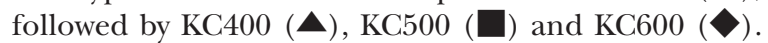
The $\mathrm{Y}$ axis is the relative signal normalized to the zero PCB response. Upper panel is the curves measured when each of the Kanechlor in DMSO was directly added to the assay solution. Middle panel is the curves measured when each of the Kanechlor in DMSO was added with the extracted solution of PCBfree transformer oil to the assay solution. In both panels, the $\mathrm{X}$ axis is the concentrations of Kanechlor in the assay solutions. In lower panel, PCB-free transformer oil was spiked with known concentrations of each of the Kanechlor into PCB-free transformer oil and then extracted. The $\mathrm{X}$ axis is the concentrations of Kanechlor in the oil.

\section{$3 \cdot 21$ 次抗体濃度と蛍光信号の関係}

本法では，測定液中の $\mathrm{PCB}$ をこれと結合平衡状態に ある未結合 1 次抗体濃度を計測することで定量する ${ }^{15) ~ 19)}$. したがって, PCBの定量には, 測定液中の未結合 1 次抗 体濃度とビーズ担体上に捕捉される抗体量を示す信号值が 直線関係にあることが望ましい. そこで，1 次抗体濃度と 信号值の関係を調べた.PCB を含まない未利用絶縁油の 前処理液を調製した。この前処理液を種々の濃度で 1 次 抗体を含む抗体溶液（2 次抗体濃度は $2 \mathrm{nM}$ 一定）に $1 \%$ （v/v）濃度で添加した。これらの測定液を自動装置に供し, Fig. 3 と同様に時間当たりの信号值の変化を測定した。そ
の結果，信号值と測定液中の 1 次抗体濃度は 500 pM まで は直線関係（相関係数は 0.974）を示したため，1\%（v/v) の絶縁油前処理液の存在下で信号值から未結合 1 次抗体 濃度を決定できると考えられた。

\section{$3 \cdot 3$ カネクロールを添加した絶縁油中の PCB 検出}

絶縁油中の PCB はカネクロール由来であると予想され る.そこで, 抗体溶液に 4 種類のカネクロール（KC300, KC400，KC500，KC600）をそれぞれ直接添加して測定を 行った。得られた信号值を，カネクロールを添加していな い試料の信号值の百分率 (相対信号值) とし, 測定液中の カネクロール濃度に対して校正曲線を作成した。先の検討 から, 信号值は測定液中の未結合 1 次抗体濃度と直線関 係にあることが分かっている.未結合 1 次抗体濃度は同 じ測定液中の PCB 濃度と結合平衡において相関があるこ とから, 相対信号值からカネクロール濃度を知ることがで きるはずである，各カネクロールの校正曲線において，検 出範囲を相対信号值が 10〜90\%の間を示す各カネクロー ル濃度とした場合，測定液において KC300 では $0.9 〜 110$ ppb, KC400 では 0.7〜 47 ppb, KC500 では 0.2〜 12 ppb, KC600 では $0.1 〜 6.6 \mathrm{ppb}$ の範囲で検出が可能であった (Fig. 4). 同様な検討を PCB を含まない未使用絶縁油の 前処理液の存在下で行った。すなわち, 未使用絶縁油の前 処理液を $1 \%(\mathrm{v} / \mathrm{v})$ となるように抗体溶液に添加した。 更に 4 種類のカネクロールをそれぞれ追加して測定液を 調製し, 測定を行った。得られた信号值は, カネクロール を追加しなかった場合の信号值の百分率（相対信号值）と し，測定液に添加したカネクロール濃度に対して校正曲線 を作成した。その結果，測定液中において KC300 では 1.5 〜 $75 \mathrm{ppb}, \mathrm{KC4} 400$ では $0.7 \sim 34 \mathrm{ppb}, \mathrm{KC5} 00$ では 0.3 $8.3 \mathrm{ppb}, \mathrm{KC6} 00$ では $0.2 \sim 7.3 \mathrm{ppb}$ の範囲で検出できた (Fig. 4).これらの検出範囲は, 先に得られた絶縁油の前 処理液を添加していない測定系とほぼ一致していたため, 本条件下では相対信号值から絶縁油中の PCB を検出でき ると予想された。そこで，PCBを含まない未使用絶縁油 にカネクロールを種々の濃度で添加し, 前処理液を調製し た。これらの前処理液を $1 \%(\mathrm{v} / \mathrm{v})$ となるように抗体溶 液に添加して測定を行った。測定の結果は，前述と同様に 相対信号值で示した。相対信号值と絶縁油中のカネクロー ル濃度から作成した校正曲線から, 油中カネクロール濃度 として KC300 では $0.3 \sim 18 \mathrm{ppm}, \mathrm{KC} 400$ では $0.2 \sim 7.1$ ppm, KC500 では $0.1 \sim 1.5 \mathrm{ppm}, \mathrm{KC600}$ では $0.1 \sim 1.5$ ppm の範囲で検出できると考えられた（Fig. 4). 以上， カネクロールを添加した絶縁油については, 前処理に続く 本測定により絶縁油中の PCB を検出できると考えられた. 

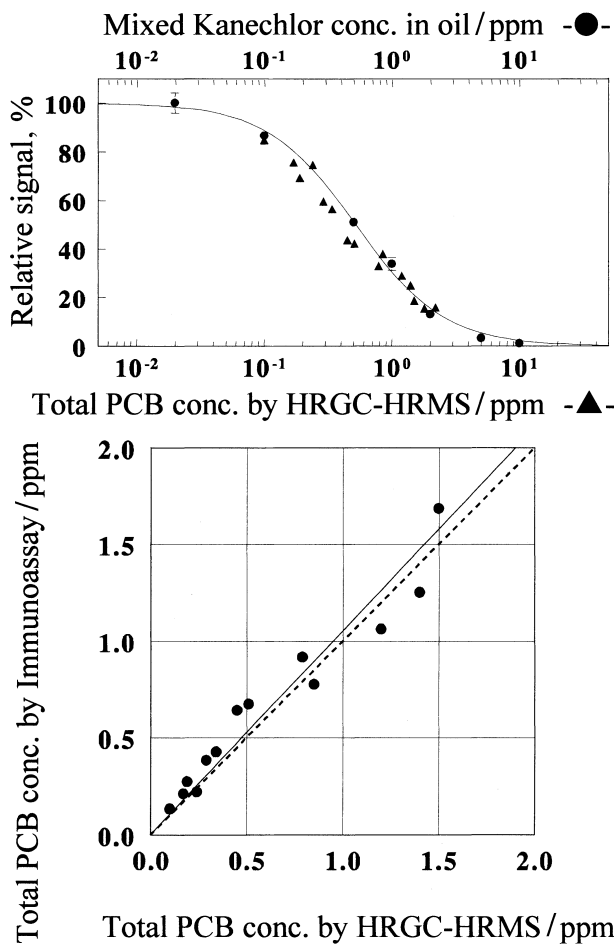

Fig. 5 Immunoassay results for 14 transformer oil samples

In upper panel, normalized immunoassay response for the transformer oil ( $\boldsymbol{\Delta}$ ) was plotted as a function of the total PCB concentrations separately determined by HRGC-HRMS. PCB-free transformer oil was spiked with known concentrations of the mixture of four types of Kanechlor (the mixed ratio is equal for each in weight). The spiked oil was then extracted for the measurement. The normalized response for the spiked oil ( ) was plotted with the concentrations of mixed Kanechlor in oil. In lower panel, concentrations of PCB in the transformer oil as measured by the immunoassay $v$ s the HRGC-HRMS. The best fit line is shown as solid.

\section{$3 \cdot 4$ 混入絶縁油中の PCB 検出}

PCB が混入した 15 種類の使用済み絶縁油から前処理液 を調製し，1\%（v/v）となるように抗体溶液に添加して測 定を行った。得られた信号值を，PCBを含まない未使用 絶縁油における信号值の百分率（相対信号值）とした。 ま た，同混入油中の総 PCB 濃度を HRGC-HRMS にて測定 し，相対信号值に対して作困した結果，Fig. 5 の相関を得 た. 更に 4 種のカネクロールの混合物（等重量の KC300, KC400，KC500，KC600 を混合）を添加した未使用絶縁油 を調製し，前処理及び測定を行って得た相対信号值を校正 曲線として Fig. 5 に作図した。この後，この校正曲線を 使用し, 混入油における相対信号值から油中の総 PCB 濃 度をカネクロールの混合物の換算值として算出した。算出 した総 PCB 濃度と HRGC-HRMS によって決定した総 $\mathrm{PCB}$ 濃度との相関を調べた結果, 相関係数として 0.957 が
得られた (Fig. 5).なお，相関を示す 1 次関数の傾きは 1.05 であり，両測定法に良い一致が認められた。以上， 前処理に続く本測定により, PCB 混入絶縁油においても 絶縁油中の総 PCB を検出できた.

$$
4 \text { 考察 }
$$

\section{$4 \cdot 1$ 前処理法}

著者らは，これまでに絶縁油の前処理法として DMSO による 2 段抽出を報告 ${ }^{20)}$ したが，前処理液を抗体溶液に $0.1 \%(\mathrm{v} / \mathrm{v})$ 以上の濃度で添加すると白濁が生じやすい問 題があった，本報告における前処理法により，白濁が生ず ることなく，これまでの約 10 倍に相当する $1 \%(\mathrm{v} / \mathrm{v})$ 濃 度で抗体溶液への添加が可能となった。結果として, DMSOによる 2 段抽出を用いた既報に比べ測定全体の感 度を約 20 倍向上できた。

本報告における前処理の PCB 回収率は, 4 種のカネク ロールを等量含む絶縁油においては，カラム処理で $92 \%$ 以上であり，続く DMSO 抽出において約 $43 \% \quad(n=1)$ であることが質量分析から分かった。更に同様にDMSO 抽出までの回収率を 4 種類の使用済み絶縁油を使って確 認したところ， $54.5 \pm 5.6 \%($ 各 $n=1 ）$ であった。更に PCB の回収率をイムノアッセイの結果からも算出した. 各カネクロールを添加した絶縁油に前処理を行って得られ た校正曲線（Fig. 4，中）と，未使用絶縁油の前処理液に 直接カネクロールを添加して得られた校正曲線（Fig. 4, 下）から, 回収率を求めた。その結果, 回収率はカネクロ ールの種類と濃度に大きく影響されず，40～60\% の範囲 であり，質量分析から求めた回収率と一致していた。

\section{$4 \cdot 2$ 検出特性}

Fig. 4 のカネクロールの校正曲線群から明らかである が，同じ相対信号值であっても，油中の PCB 同属体組成 により総 PCB 濃度が異なる場合が起こりうる。これは, 測定法よりも抗体の交差性に起因する問題である。今回用 いた抗 PCB 抗体は，相対的に $5 \sim 6$ 塩素同属体を多く含 む KC500 や KC600 に良い結合性を示す一方，3４塩素 同属体を多く含む KC300 や KC400 には結合性が劣ってい た（Fig. 4）。しかし，実際の PCB 混入絶縁油について測 定を行った場合，測定点に限りがあるものの，カネクロー ルの混合物（4種のカネクロールを等重量混合）換算では, 総 PCB 濃度において HRGC-HRMS と良い相関が得られた (Fig. 5). これは, 本測定法が結合平衡除外効果を有し ${ }^{15)}$, 検出特性が用いた抗体の結合親和性に直接反映されること によるところが大きい.すなわち，相対信号值は測定液中 に存在する PCB 同属体に対する親和性の総和として示さ れるので，抗体に結合しやすい同属体濃度に最も影響され る。したがって, 本抗体を用いた測定では, 絶縁油中の 
$\mathrm{PCB}$ のうち KC500 や KC300 由来の同属体の組成比が大き く変化しなければ, 総 PCB 濃度はカネクロールの混合物 を用いた換算值から大きく逸脱しないと考えられた。

\section{文献}

1) 野馬幸生, 安原昭夫, 酒井伸一: 安全工学, 40,353 (2001).

2) 野馬幸生: 廃裹物学会誌, 9, 247 (1998).

3) R. O. Harrison, G. H. Edulijee: Sci. Total. Environ., 239, 1 (1999).

4) US EPA Method 4020, Screening for polychlorinated biphenyls by immunoassay (2003).

5) J. Zajicek, D. E. Tillet, T. R. Schwartz, C. J. Schmit, R. O. Harrison: Chemosphere, 40, 539 (2000).

6) S. Jaborek-Hugo, C. von Holst, R. Allen. T. Stewart, J. Willy: Food. Addit. Contam., 18, 121 (2001).

7) 佐藤正光: 水, 40 (10), 24 (1998).

8) 大野良文, 兒杵靖晃: 作業環境, 25 (3), 32 (2004).

9) 古庄義明, 高柳 学, 今中努志, 林田寛司, 白井 淳, 田中興三次郎: 産業と環境, 32 (10), 97 (2003).

10）滝上英孝，光原好人，松山喜代志，酒井伸一: 廃棄 物学会第 15 回研究発表会講演論文集, p. 1337
(2004).

11) 酒井伸一，滝上英孝，細江和典，ピーター・ベー ニッシュ：廃裹物学会誌, 14, 34 (2003).

12) H. Takegami, K. Hosoe, P. A. Behnisch, K. Shiozaki, H. Mizukami, M. Ohno, S. Sakai: Organohalogen Compounds, 58, 397 (2002).

13）滝上英孝，鈴木 剛，野馬幸生，酒井伸一：環境化 学, 14, 791 (2004).

14) 滝上英孝，酒井伸一：ぶんせき (Bunseki), 2003, 502.

15) N. Ohmura, S. J. Lackie, H. Saiki: Anal. Chem., 73, 3392 (2001).

16) N. Ohmura, Y. Tsukidate, H. Shinozaki, S. J. Lackie, H. Saiki : Anal. Chem., 75, 104 (2003).

17) T. R. Glass, H. Saiki, D. A. Blake, R. C. Blake, S. J. Lackie, N. Ohmura: Anal. Chem., 76, 767 (2004).

18) T. R. Glass, N. Ohmura, H. Saiki, S. J. Lackie: Anal. Biochem., 331, 68 (2004).

19) T. R. Glass, H. Saiki, T. Joh, Y. Taemi, S. J. Lackie, N. Ohmura: Biosensors and Bioelectronics, 20, 397 (2004).

20) T. R Glass, N. Ohmura, Y. Taemi, T. Joh: Environ. Sci. Technol., 39, 5005 (2005).

要旨

絶縁油中ポリ塩化ビフェニル（PCB）の簡易測定として，前処理法並びに自動装置を用いたイムノアッセ イ法を検討した。絶縁油を発煙硫酸・硫酸含浸珪藻土カラムとシリカゲルカラムを連結した二段カラムによ り処理し，続いてジメチルスルホキシド抽出を行う前処理法を確立した。前処理に扔けるPCB の回収率は $40 \sim 60 \%$ であり, 所要時間は 30 分程度であった．前処理液を抗 PCB 抗体溶液に添加し，自動イムノアッ セイ装置に供した結果，約 8 分間で分析が可能であった。検出範囲は絶縁油に添加したカネクロール (KC) 300 で $0.3 \sim 18$ ppm, KC400 で $0.2 \sim 0.7$ ppm，KC500 と KC600 では共に $0.1 \sim 1.5$ ppm であった. 更に 15 種の PCB 混入絶縁油について，本法と高分解能質量分析により決定した総 PCB 濃度（0.1 1.8 ppm）の間 には高い相関があった。 